\title{
OIL PALM MALE MEIOSIS PROFILING: FROM FIELD OBSERVATION TO CYTOGENETICS ANALYSIS
}

\author{
NORDIANA, H M N*; MADON, M*,**; SINGH, R*; SRITHARAN, K; MUHAMMAD AZWAN, Z* \\ and ZAKI, $\mathbf{N ~ M}^{*}$
}

\begin{abstract}
Male meiosis is a principal process in microsporogenesis, important for male fertility and gamete viability in higher plants. This division ensures genome stability of sexually reproducing organisms and creates genome variation enabling diversity in a species. We present a structured profiling of male meiosis in the interspecific oil palm hybrid, Elaeis oleifera $\times$ Elaeis guineensis $(O x G)$, for an in-depth understanding of the process. In the pollen mother cells (PMC), interaction between the parental genomes was observed in early prophase I, via genomic in situ hybridisation (GISH). At this meiosis I stage, the chromosome pairing revealed 16 complete bivalents, confirming the homologous pairing of each E. guineensis and E. oleifera chromosomes. Interestingly, we found that the E. guineensis and E. oleifera pollens had distinct morphologies, which represents another feature that differentiates the two species. This could also be used as a basis diagnostic tool to evaluate sterility in oil palm interspecific hybrids.
\end{abstract}

Keywords: meiosis, chromosome pairing, oil palm pollen.

Received: 18 August 2020; Accepted: 22 October 2020; Published online: 4 December 2020.

\section{INTRODUCTION}

Oil palm is from the genus Elaeis (Arecaceae), a perennial monocot with a single apical meristem. The genus has two interfertile species - the African E. guineensis Jacq. and Central/South American E. oleifera. Both species are diploid $(2 n=32)$, apparently evolved from an ancient tetraploid species (Madon et al., 2005; Singh et al., 2013). Their genome structure and organisation appear quite similar (Singh et al., 2013). E. guineensis is planted

\footnotetext{
Malaysian Palm Oil Board,

6 Persiaran Institusi, Bandar Baru Bangi,

43000 Kajang, Selangor, Malaysia.

E-mail: hariza@mpob.gov.my

** 9, Jalan BM 5/12, Bandar Bukit Mahkota, 43000 Kajang, Selangor, Malaysia.

‡ United Plantations Berhad, Jenderata Estate, 36009 Teluk Intan, Perak, Malaysia.
}

commercially in most oil palm growing countries, due to its higher yield, while E. oleifera only in places where disease(s) devastates E. guineensis. Nevertheless, E. oleifera has interesting traits that benefit the E. guineensis - slower growth, resistance to certain diseases and less saturated oil with higher carotene (Hardon, 1969; Meunier, 1987; Choo et al., 1997; Choo and Yusof, 1996; Amiruddin et al., 2004) - and it has been the ultimate aim to introgress them into E. guineensis (Hardon, 1969; Rajanaidu et al., 1995; Escobar and Alvorado, 2003; Amiruddin et al., 2004).

Both monoecious species produce separate male and female inflorescences in alternating phases, influenced by both genetic and environmental factors. The main abiotic factor that influences the sex determination is stress. Anything that detracts from photosynthesis producing more carbohydrates for greater vigour, such as too much/little water and high-density planting, will favour the production of male inflorescences (Corley and Gray, 1976; Barcelos et al. 2015). The sex ratio of a palm (number of female inflorescences: total inflorescences) 
(Corley and Tinker, 2003) is an important criterion that determines its yield. A higher sex ratio is generally better for producing more fruit bunches, but excessively high ratios would mean a dearth of male inflorescence/pollen, and denying the female inflorescences of their wherewithal for pollination and fruiting. There has to be a delicate balance in the sex ratio, at any one time, for the desired yield to be realised. A detailed examination of the basic biological process that produce both male and female sex cells in oil palm will be helpful to strategise for higher level of productivity.

The reproductive cells in plants are produced via meiosis, a fundamental inheritance process that occurs in the anthers of male and ovaries of female flowers. In meiotic prophase I, two distinct events occur - homologous chromosome pairing and synapsis, in which the bivalent chromosomes become condensed and distinguishable (Hurel et al., 2018).

Genomic in situ hybridisation (GISH) allows visualisation of the homoeologous and homologous chromosome pairing at meiosis, especially in prophase I. The technique further allows detection of chromosome rearrangement, or translocation, and commonly used to evaluate chromosome pairing during meiosis (Schubert et al., 2001; Maluszynska and Hasterok, 2005; Gao et al., 2016). GISH involves labeling of chromosomes or an entire genome in plant hybrids, where total genomic deoxyribonucleic acid (DNA) is used as a probe on chromosome spreads (Anamthawat-Jonsson and Heslop-Harrison, 1995). The technique is generally useful in distinguishing parental genomes in both intergeneric (Leitch et al., 1991; Belandres et al., 2015) and interspecific hybrid plants (Schwarzacher et al., 1992; Abd El-Twab and Kondo, 2007).

Principally, pollen is the end product of meiosis in the male gametic cell, after recombination and reassertion of the chromosomes. Microspores (immature pollen) and pollen are derived from the pollen mother cells (PMC) in pollen sacs. Oil palm belongs to the tribe Cocoaeae, subfamily Arecoideae. Generally, pollen morphology is known to be distinctive for each tribe. The primary aperture type found in this subfamily is monosulcate while trichotomosulcate pollen is only found in E. guineensis (Rasheed et al., 2016). The pollen of E. oleifera has yet to be described, especially its differences, if any, with that of E. guineensis pollen. As plant hybridisation has been known to affect the pollen features, it is anticipated that the pollen morphology of oil palm hybrid might be different than the parental types.

Despite the many studies on meiosis and pollen in other plants, similar researches on oil palm are not many. Hardon and Tan (1969) had reported on the meiotic cytology of interspecific hybrids
(E. guineensis $\mathrm{x}$ E. oleifera) and showed that the pachytene chromosomes were normally paired except for the occasional segments. Subsequently, Madon et al. (2005) described the basic cytology of E. guineensis PMC in an effort to identify two important stages: pachytene and uninucleate stages that will facilitate research. Similarly, apart from histo-anatomical analysis on the E. oleifera reproductive system, De Farias et al. (2018) also observed the different meiosis and pollen stages, but did not describe the pollen morphology.

This study aims to provide graphical information on male meiosis in oil palm interspecific hybrids. The pairing of the homologous chromosomes of both parental species was observed. In addition, the distinct pollen shapes in the genus Elaeis and its interspecific hybrid are also described for the first time. Our findings will provide basic but important information on meiotic recombination in oil palm, apart from the pollen morphology, which can assist in making informed decisions in interspecific breeding of oil palm.

\section{MATERIALS AND METHOD}

\section{Plant Materials}

Young and mature male inflorescences (Figure 1) from E. guineensis and E. oleifera were sampled from MPOB Kluang, Johor, Malaysia. The inflorescences harvested were still enveloped in their spathes and were identified based on morphological criteria as described by Latif et al. (2014). The particular inflorescence to be harvested (whether containing PMC or microspores) was determined based on the description by Madon et al. (2005). Generally, the younger inflorescences with whitish buds of soft texture bear PMC, while those mature, with slightly yellowish hard buds should contain microspores.

The PMC are the precursors of microspores which then develop into pollen. The younger inflorescences, subtended by frond numbers 12-17 will have PMC, and those from frond numbers 1825 bear microspores to pollen (Madon et al., 2005; Latif et al., 2014). The desired inflorescences were selected based on their subtending frond numbers and morphology. However, De Farias et al. (2018) had suggested that most meiotic stages in E. oleifera could be found in the inflorescence on frond 14, of which, this criterion was not used in the study.

For meiotic chromosome pairing analysis, male inflorescences from an oil palm interspecific hybrid $(\mathrm{O} \times \mathrm{G})$ created from a cross between a Colombian oleifera and Nigerian guineensis, were harvested from United Plantations, Teluk Intan, Perak, Malaysia. Spear leaves of the parental palms were provided by the Genomics Laboratory, MPOB. 


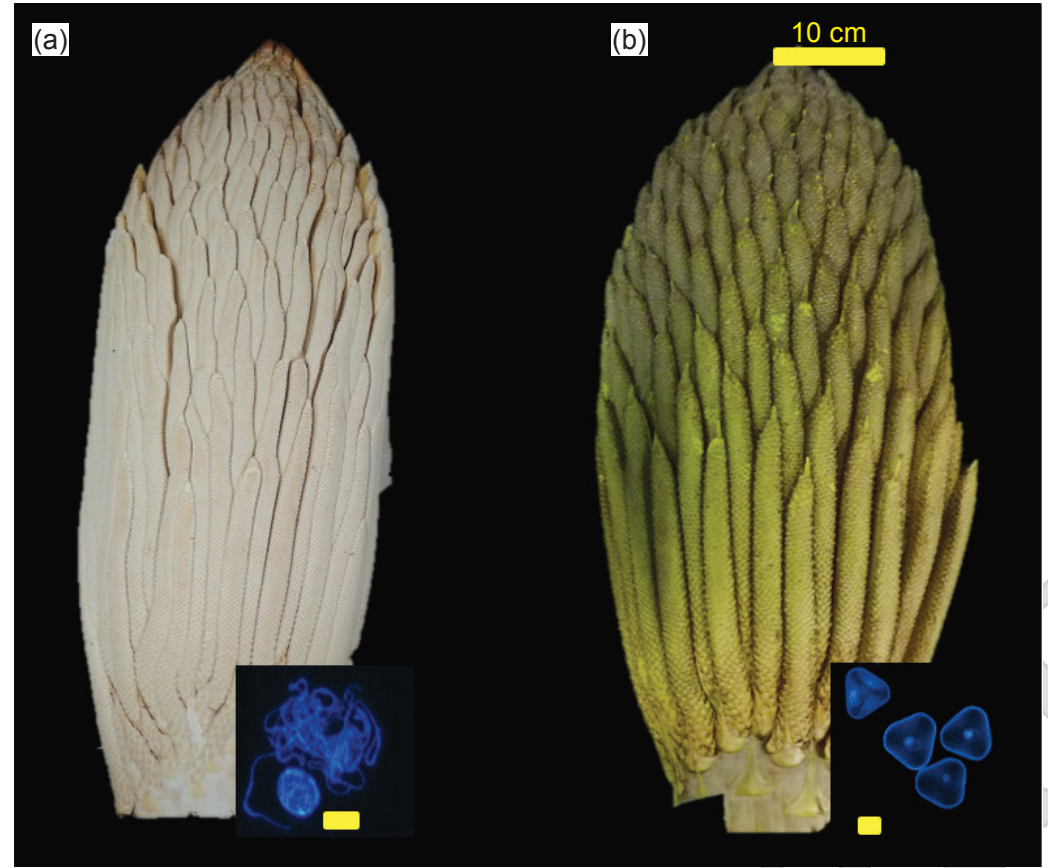

Figure 1. Oil palm male inflorescences (a) young OxG hybrid inflorescence (left) bearing pollen mother cells (PMC) (left inset), and (b) mature E. guineensis inflorescence (right) bearing microspores (right inset) (inset bar $=20 \mu \mathrm{m}$ ).

Microspores and Chromosome Staining with 4',6-diamidino-2-phenylindole (DAPI)

The process from harvesting of the male inflorescence to the preparation of the chromosomes spreads is shown in Figure 2. The young spikelet with whitish immature buds appeared crisp while the older ones with mature buds are somewhat stringy. A bud from the spikelet was put on a pre-cleaned microscope slide with a $12 \mu \mathrm{l}$ drop of $1.25 \mu \mathrm{g} \mathrm{ml}^{-1}$ DAPI (Sigma, USA), then squashed with a tweezer. The husk debris was then removed and a clean coverslip was applied to cover the 'suspension'.

\section{Chromosome Preparation}

The desired meiosis stage that was stained with DAPI was observed under a fluorescent microscope. Male flower buds at the approximate desired meiotic stage were fixed in ethanol-glacial acetic acid $(3: 1 \mathrm{v} / \mathrm{v})$ and stored at $4^{\circ} \mathrm{C}$ for up to several months. Meiotic preparation was carried out according to Nordiana et al. (2016) with minor modification. Anthers from the fixed buds were thoroughly washed with distilled water and $1 \times$ citrate buffer $(10 \times$ citrate buffer consists of $100 \mathrm{mM}$ citric acid and $100 \mathrm{mM}$ tri-sodium citrate, $\mathrm{pH}$ 4.6) for $10 \mathrm{~min}$ and then digested in $50 \mu \mathrm{l}$ of enzyme solution containing $1 \%(\mathrm{w} / \mathrm{v})$ cellulase from Aspergiller niger (Sigma Aldrich, USA, C-1184): 1\% (w/v) pectolyase from Aspergiller japonicus (Sigma Aldrich, USA, P-3026): 1\% (w/v) cytohelicase from Helix pomatia (Sigma Aldrich, USA, C-8274) for $4 \mathrm{hr}$ at $37^{\circ} \mathrm{C}$. Following the digestion, the anthers were thoroughly rinsed with $1 \times$ citrate buffer for 15 min. Two anthers were macerated on a pre-cleaned glass slide in a drop of $60 \%$ acetic acid. The PMC were released and dispersed using the squashing technique after applying the coverslip on the suspension. The prepared slides were frozen, the coverslips were removed and the slides were airdried before use for GISH analysis.

\section{Preparation of Total Genomic Probe and Block}

Total genomic DNA of the parental palms, E. oleifera (UP1026) and E. guineensis (T128), was extracted from their spear leaves using the modified cetyl trimethylammonium bromide (CTAB) method described by Doyle and Doyle (1990), and the quality of the DNA was evaluated as described by Rahimah et al. (2006). The DNA of E. oleifera (1 $\mu \mathrm{g})$ was directly labelled with biotin molecules using the BioPrime $^{\mathrm{TM}}$ DNA Labelling System Kit (Invitrogen, USA) for use as probe. The DNA of E. guineensis was fragmented by autoclaving for $5 \mathrm{~min}$ at 15 psi for use as block, as the quantity needed was 140X (140 $\mu \mathrm{g})$ more than the probe. The autoclaved DNA was stored at $-20^{\circ} \mathrm{C}$ before use.

\section{Genomic in situ Hybridisation (GISH)}

GISH was performed according to Madon et al. (1999) and Schwarzacher and Heslop-Harrison (2000) with slight modifications. The prepared slides were pre-treated with RNase A [100 $\mu \mathrm{g} \mathrm{ml}^{-1}$ RNase A in $2 \times$ saline sodium citrate (SSC) at $37^{\circ} \mathrm{C}$ for $1 \mathrm{hr}$, and then soaked in $0.01 \mathrm{M} \mathrm{HCl}$ for $2 \mathrm{~min}$. The slides 
(a)
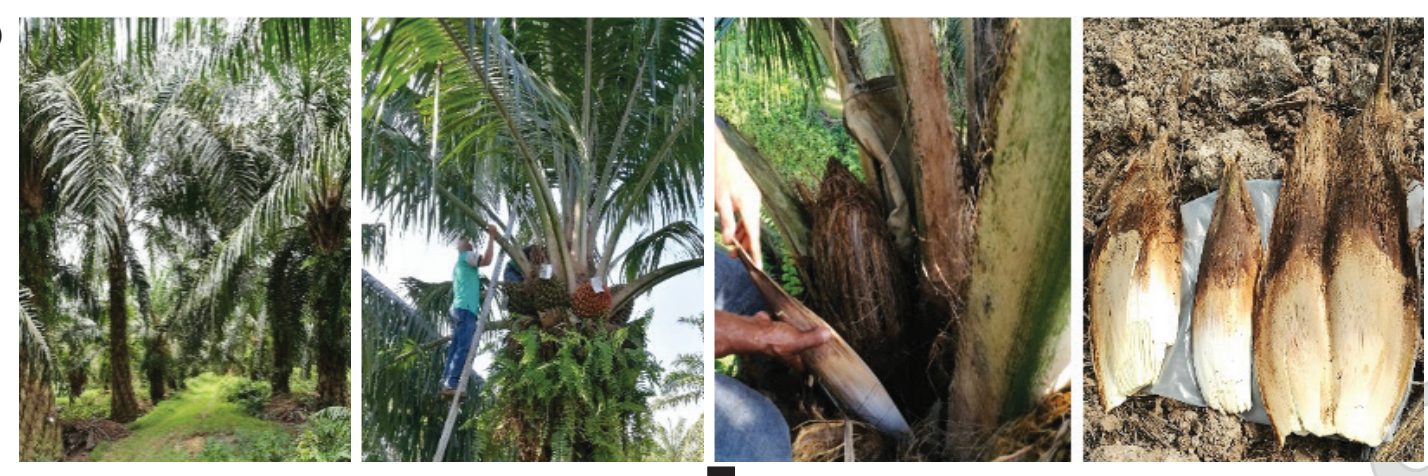

(b)
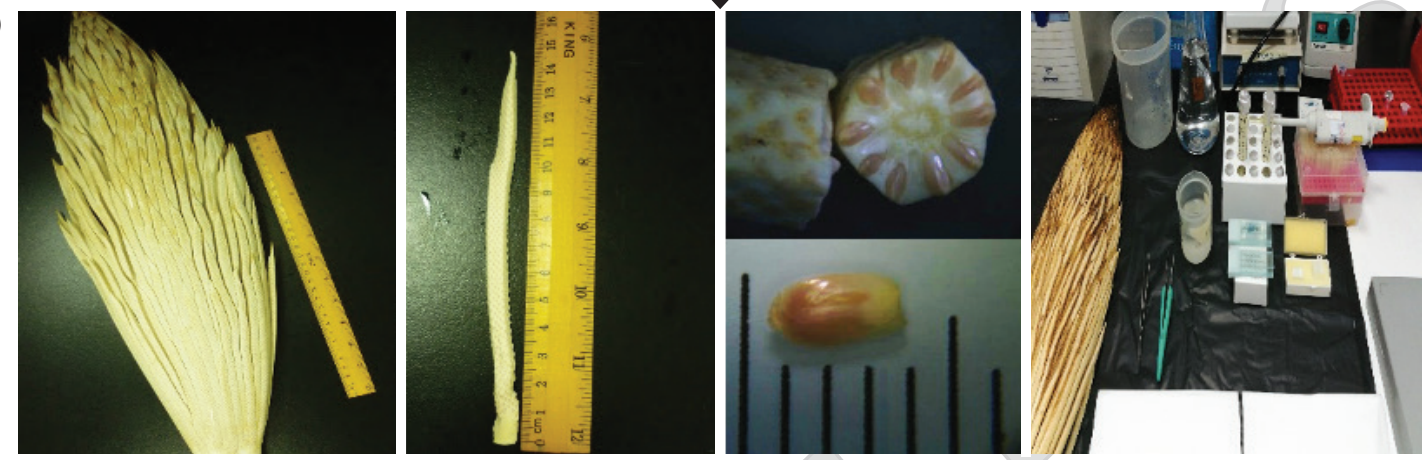

(c)
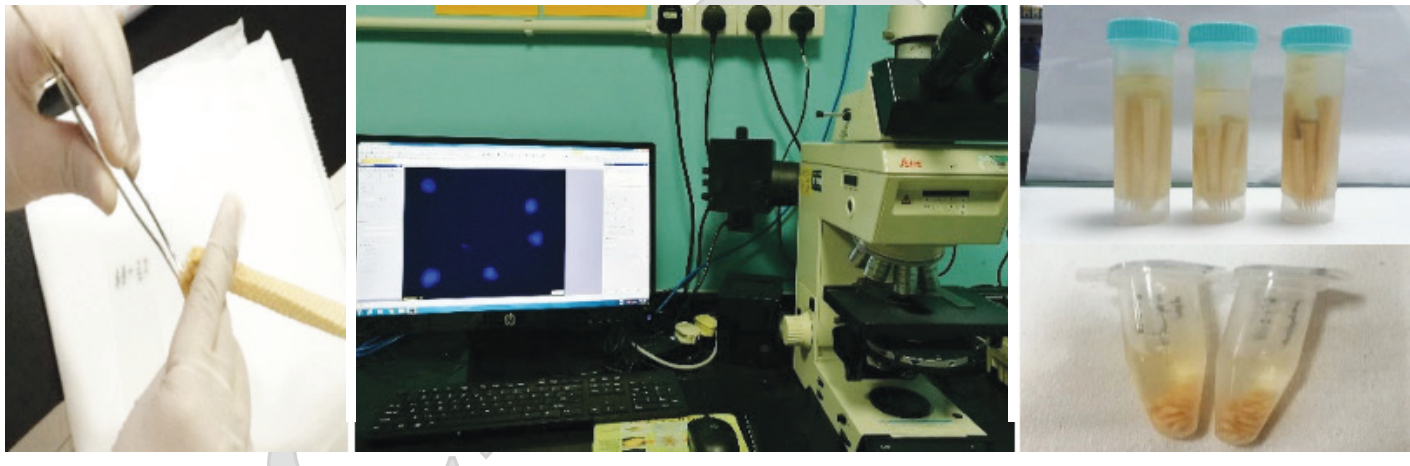

Figure 2. Isolation of pollen mother cells (PMC) and microspores - from field to microscope. (a) Selection (mentioned in materials above) and harvesting of male inflorescence (left to right) (b) harvested male inflorescence brought to laboratory and processed (left to right) (c) preliminary screening by 4',6-diamidino-2-phenylindole (DAPI) staining viewed under microscope. Spikelet and buds with desired stages fixed for use (left to right).

were then treated with pepsin solution for $10 \mathrm{~min}$ at $37^{\circ} \mathrm{C}$ and washed in $2 \times \mathrm{SSC}$ for $5 \mathrm{~min}$. The slides were then post-fixed with $4 \%$ paraformaldehyde, washed with 2× SSC, dehydrated in different concentrations of ethanol $(70 \%, 85 \%$ and $100 \%)$ and left to air dry. A total $40 \mu$ l of probe and block hybridisation mixture with final concentration of $5 \mathrm{\mu g} \mathrm{ml}^{-1}$ was prepared per slide, containing $50 \%$ $(\mathrm{v} / \mathrm{v})$ formamide, $10 \%(\mathrm{w} / \mathrm{v})$ dextran sulphate, $2 \times$ SSC, $0.125 \%(\mathrm{w} / \mathrm{v})$ sodium dodecyl sulphate, $0.125 \mathrm{mM}$ ethylenediamine-tetraacetic acid. The mixture was denatured for $10 \mathrm{~min}$ at $70^{\circ} \mathrm{C}$, then immediately cooled on ice for another $10 \mathrm{~min}$. A total of $40 \mu \mathrm{l}$ of hybridisation mixture was dropped on one slide and a plastic coverslip was applied. The hybridisation mixture and chromosomal DNA (the slides) were denatured together on Hybaid
Omnislide thermal cycler (Fisher Scientific, USA) at $80^{\circ} \mathrm{C}$ for $13 \mathrm{~min}, 58^{\circ} \mathrm{C}$ for $35 \mathrm{~min}$ and allowed to cool to the hybridisation temperature of $37^{\circ} \mathrm{C}$ overnight (up to $20 \mathrm{hr}$ ).

The following day, the slides were washed in $2 \times$ SSC for $3 \mathrm{~min}$ at $42^{\circ} \mathrm{C}$, rinsed twice for $5 \mathrm{~min}$ at $42^{\circ} \mathrm{C}$ in $20 \%(\mathrm{v} / \mathrm{v})$ formamide in $0.1 \times$ SSC, twice for $5 \mathrm{~min}$ at $42^{\circ} \mathrm{C}$ in $0.1 \times$ SSC, once for $5 \mathrm{~min}$ in $2 \times$ SSC at room temperature (RT) and twice for $5 \mathrm{~min}$ in detection buffer (4x SSC / $0.2 \%$ Tween) at RT. Blocking solution [5\% $(\mathrm{w} / \mathrm{v})$ bovine serum albumin (BSA) in detection buffer] was applied to the slides for $5 \mathrm{~min}$ at RT. The biotin-labeled probe was detected with $2 \mu \mathrm{l}$ streptavidin-CF594 conjugate antibody, $200 \mu \mathrm{g} \mathrm{ml}^{-1}$ (Biotium, USA) in blocking solution. Slides with the antibody were incubated in a moist chamber at $37^{\circ} \mathrm{C}$ for $1 \mathrm{hr}$. The slides were subsequently washed 
in detection buffer three times for $5 \mathrm{~min}$ each, to remove the surplus antibody at RT. A drop of $10 \mu \mathrm{l}$ ready-to-use EverBrite ${ }^{\mathrm{TM}}$ mounting medium with DAPI (Biotium, CA, USA) was used to counterstain the chromosomes after which they were covered with a glass coverslip.

All the chromosomes slides were viewed and captured under a Leica DMRA fluorescent microscope (Leica Microsystems, Germany) with an Olympus DP73 camera and the images analysed using Olympus CellSens Dimension Imaging Software Version 1.14 (Olympus Corp, Japan).

\section{RESULTS AND DISCUSSION}

\section{Male Meiosis Profile of Oil Palm Interspecific Hybrid}

We successfully identified all the essential stages of meiosis in oil palm hybrid male inflorescences, occurring as in angiosperms (Figure 3). Figures 3a-e show prophase 1 with its five known substages - leptotene, zygotene, pachytene, diplotene and diakinesis. Synapsis (pairing) of the chromosome homologues was clearly observed at zygotene, followed by the chromosomes continuing to shorten and thicken at pachytene. The homologous recombination between the parental chromosomes occurs at this stage. The pachytene stage of early meiotic prophase has been extensively studied by cytologists as it provides a unique view of the organisation of haploid genomes (Murphy and Bass, 2012). Using GISH assay, De Farias et al. (2018) observed high homology between the chromosomes of the two species when the E. guineensis genome was hybridised on E. oleifera pachytene chromosomes. The elongated, synapsed fibres at this stage have been applied to assess the organisation of the rice genome (Kim et al., 2005) and to build fluorescence in situ hybridisation (FISH) cytogenetic maps, which are ideal for comparative mapping studies and evaluating the quality of the genome sequence assembly in tomato, maize, cucumber and barley (Zhong et al., 1996; Figueroa and Bass, 2012; Lou et al., 2013; Phillips et al., 2013). The transition from pachytene to early diplotene occurs when the elongated chromosomes transform to a compact spindly-looking bivalent fibre configuration. The bivalent fibres continue to separate along their length and eventually become detached. Further chromosome compaction occurs in the transition to diakinesis. The bivalent chromosomes at this stage have been used to study meiotic pairing, as in the intergeneric hybrids of $x$ Brassicoraphanus, where the pairing of their parental genomes was observed (Belandres et al., 2015).

The bivalent chromosome pairs align during metaphase I at the equator of the cell (Figure 3f).
The PMC are in uninucleate, or one-nucleus state. Gao et al. (2016) evaluated the chromosome pairing in two population of Roegneria sinica var. media where it occurred mainly between homologous chromosomes. The homologous chromosomes then separate, and the two sets move to opposite poles of the cell in anaphase I (Figure $3 g$ ). At telophase I, the chromosome sets arrive at their respective poles and nuclear membrane reappear resulting in two daughter nuclei. A cleavage line appears and gradually divide into two daughter cells (dyad) known as successive cytokinesis (Figure $3 h$ ).

Following the formation of two daughter cells, the meiotic II division starts which essentially is a mitotic division. In metaphase II, the chromosomes once again orientate on the equatorial plane and divide (Figure 3i). The chromatids are then pulled to their respective opposite poles. At the end of telophase II, tetrad eventually gives rise to immature pollen with haploid chromosome number $(n=16)$, also known as microspores (Madon et al., 2005).

Immature pollens from the PMC are known as uninucleate microspores. Their transition to binucleate occurs through mitosis (Figures 3l-3n) (Latif et al., 2014). At the end, these two nuclei have different functions, one as a vegetative and the other as a generative nucleus. Microspore culture has been carried out to develop haploid plants, such as in barley, hazelnut and pepper ( $\mathrm{Li}$ and Devaux, 2001; Karasawa et al., 2016; A ta et al., 2019). This was also attempted for oil palm from uninucleate and binucleate microspores, but oil palm turned out to be recalcitrant to microspore culture, especially in the induction of embryogenesis (Latif et al., 2013).

According to De Farias et al. (2018), E. oleifera meiosis occurs acropetally, from base to apex. A similar acropetal pattern of meiosis development was also observed for E. guineensis and OxG hybrids. Thus, both Elaeis sp. and their hybrids go through a similar meiosis pattern (Madon et al., 2005; De Farias et al., 2018). This also occurs in Arabidopsis sp. and Triticum aestivum (Armstrong et al., 2009; Higgins et al., 2014; Able et al., 2009).

\section{Chromosome Pairing in Early Prophase I in OxG Hybrid}

Previously, GISH had differentiated 16 E. oleifera and 16 E. guineensis chromosomes on the mitotic metaphase spread of an OxG hybrid (Madon et al., 2005). However, the composition of the parental chromosomes varied in the backcross one $\left(B_{1}\right)$ progenies (Madon et al., 2018). In early meiotic prophase I, the maternal and paternal homologues of each chromosome undergo exact pairing into bivalents. In this study, bivalents are regularly observed on the chromosome spreads. GISH clearly differentiated the 16 bivalent pairs, 

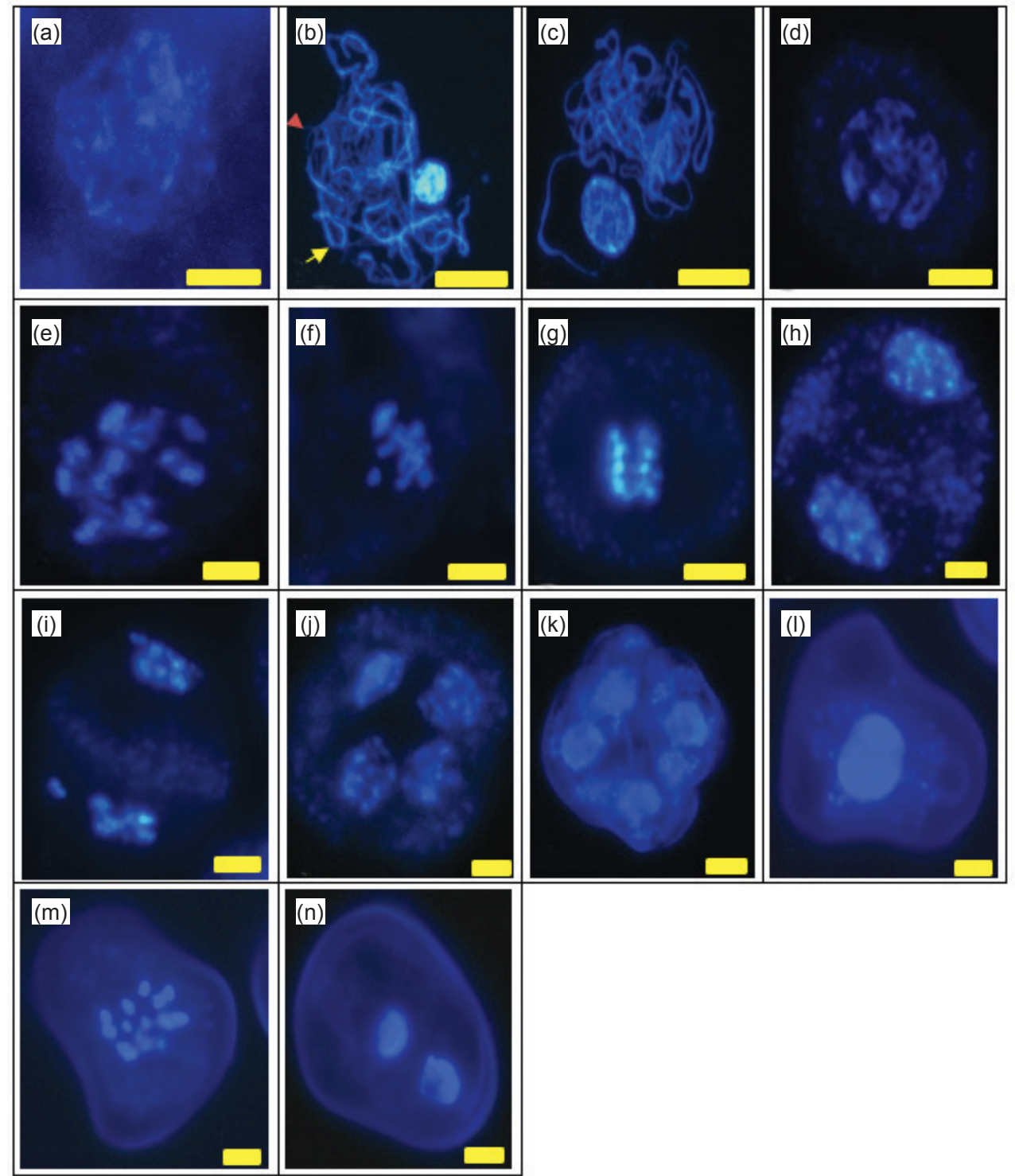

Figure 3. Cytology of male meiosis in oil palm interspecific hybrid. (a) Premeiotic interphase, (b) zygotene with paired (yellow arrow) and unpaired (red arrowhead) chromosomal regions, (c) pachytene with complete paired chromosomes, (d) diplotene, (e) diakenesis showing unaligned bivalents, (f) metaphase i, ( $g$ ) anaphase $i,(h)$ prophase ii (two daughter cells formation), (i) metaphase ii, $(j)$ tetrad, ( $k$ ) unreleased microspores, (l) uninucleate (one nucleus state) microspore $(m)$ microspores with 16 chromosomes $(n)$ mid-binucleate microspores with two nuclei. DNA counterstained with 4',6-diamidino-2-phenylindole (DAPI) (bar $=20 \mu \mathrm{m})$.

each pair containing the red fluorescence signals of the E. oleifera genomic DNA used as probe, while the E. guineensis contributed the blocking DNA. Figure 4 shows the homologous pairing between two chromosomes at diakinesis, one coming from each parent, forming 16 bivalents in all. These reflect the close homology between the E. oleifera and E. guineensis chromosomes. Hardon and Tan (1969) had reported the frequent formation of bivalents in meiosis I in E. guineensis $\times$ E. oleifera $\mathrm{F} 1$ hybrids, but there has been no information on the pairing of the parental genomes in early meiosis until now.

Cytogenetic studies on meiotic chromosome pairing have been done on other plants, for example, high frequency bivalent formation and regular meiosis in Lolium perenne $\times$ Festuca pratensis hybrids by Thomas and Thomas (1973), while Belandres et al. (2015) discriminated 10 pairs of Brassica bivalent chromosomes in a new synthetic intergeneric hybrid $\times$ Brassicoraphanus line. In a related study, Fukuhara et al. (2016) observed frequent formation of bivalents in an interspecific hybrid of Jatropha, suggesting the presence of homoeologous chromosomes in the Jatropha curcas $\times$ J. integerrima hybrid.

\section{Pollen Morphology of Elaeis sp. and OxG Hybrid}

The pollen of both oil palm species have distinct shapes (Figure 5). E. guineensis pollen is triangular and E. oleifera pollen ellipsoid, in symmetric and asymmetric forms. The OxG pollen is a hodgepodge of the two, being triangular-ellipsoidal. Ravi Kumar and Nair (1986) reported the pollen shapes in three Gloriosa sp. and three of their hybrids (including 


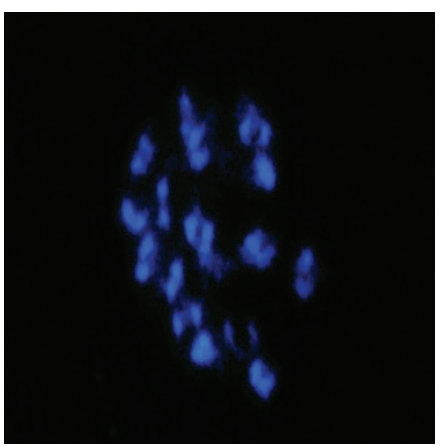

Probe

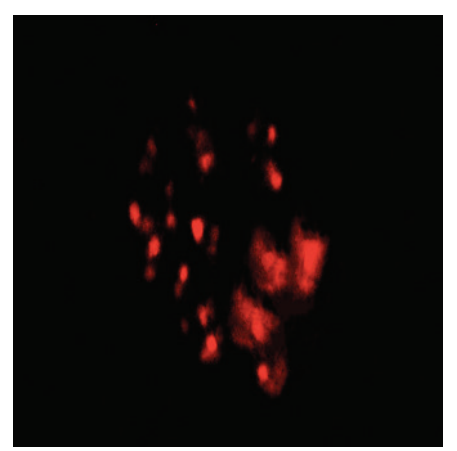

DAPI

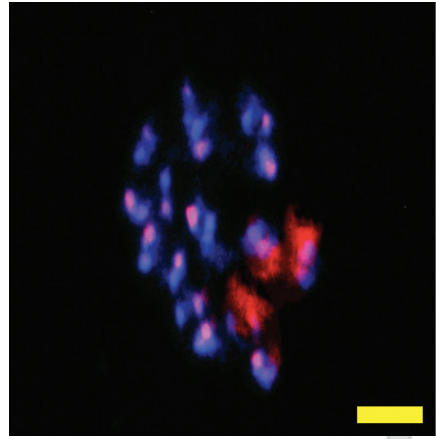

Merged

Figure 4. The genomic in situ hybridisation (GISH) on meiotic chromosomes, probed with BioPrime-labeled total genomic DNA (1 $\mu \mathrm{g})$ from UP1026, and detected with fluorescent dye CF594 (red) and 140X blocking DNA of T128 counterstained with 4',6-diamidino-2-phenylindole (DAPI) (blue). In the merged image, there are 16 bivalents, each the pairing of one oleifera (red) and one guineensis (blue) chromosome $($ bar $=20 \mu \mathrm{m})$.
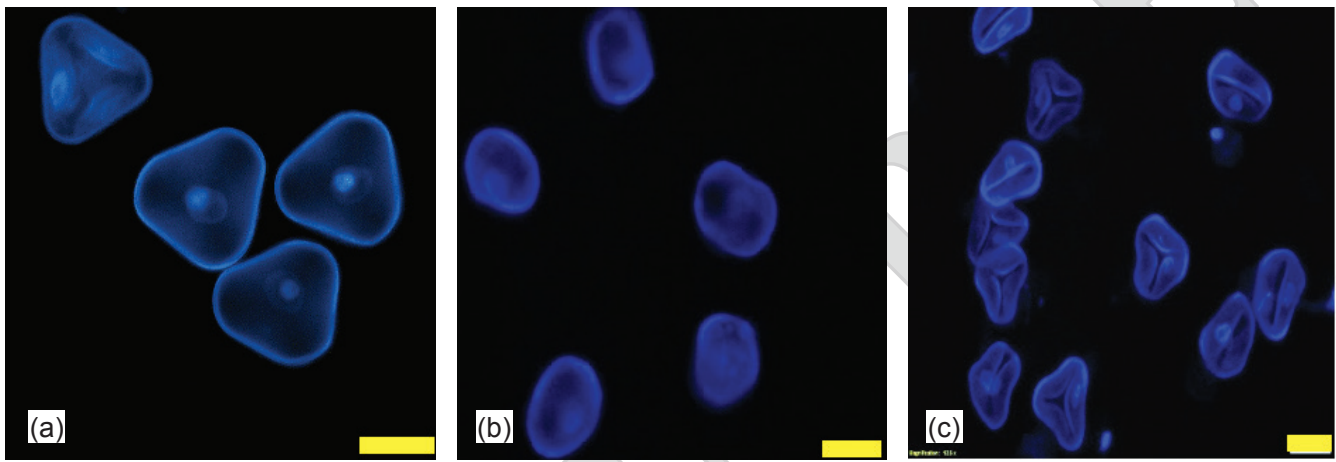

Figure 5. Pollen in (a) E. guineensis showing triangular shape (b) E. oleifera showing ellipsoid shape, and (c) OxG hybrid showing a hodgepodge of both parental morphologies ( $b a r=50 \mu \mathrm{m}$ ).

the reciprocal crosses). In the hybrids, $70 \%-100 \%$ of their pollen resembled those of their respective female parent, suggesting a strong maternal influence on the pollen shape. Similarly, Rhee et al. (2005) observed that the pollen morphology of interspecific hybrids of lilies after chromosome doubling highly resembled those of their mother plants. In weeds, the size of Amaranthus hybrid pollen was similar to that of the maternal parent but had intermediate aperture numbers between both parents (Franssen et al., 2001), also suggesting a strong maternal influence.

The pollen of both species are aperturate, i.e., having clear apertures on their pollen wall. Harley and Baker (2001) opined that pollen shape is often related to their aperture type, for example, monosulcate aperture (only one opening) with ellipsoidal pollen, as in E. oleifera and trichotomosulcate aperture (with three openings) often with trianguloid pollen, as in E. guineensis (Figure 6). In the tribe Cococeae, Rasheed et al. (2016) described the pollen shape are frequently elliptical, but occasionally oblate-triangular pollen are also observed. In some species, the aperture of monosulcate, and, at times, trichotomosulcate pollen can range from being symmetric to asymmetric.

E. guineensis and Cocos nucifera (coconut) pollen are easily distinguished by their aperture and exine pattern. C. nucifera has monosulcate pollen and E. guineensis trichotomosulcate. Cluster analysis revealed that $E$. guineensis is not in the same clade as other aeroids because of its trichotomosulcate pollen (Rasheed et al., 2016). However, the triangular E. guineensis pollen does have some similarity with that of Sclerosperma sp. (Arecaceae) as described by Grimsson et al. (2018). Although no observation of aperture pattern was made on E. oleifera by Rasheed et al. (2016), this study found that the aperture pattern and subsequent pollen shape are similar to those in C. nucifera. Furthermore, the date palm (Arecaceae family) also produces elliptical-oblate and monosulcate pollen (Jazinizadeh et al., 2017).

Nair (1969) suggested that the shapes of pollen could be associated to their functions, hence selection based on morpho-physiological traits may assist in breeding efforts. In Lilium sp., a malformed pollen shape was observed in a sterile F1 (Rhee et al., 2005). Interestingly, a similar abnormality was also found in sterile interspecific hybrids of Lagerstroemia indica and L. speciose (Ju et al., 2019). Hence, the distinct pollen shapes and features identified in this study could form a basis in the development of a diagnostic tool to evaluate sterility in interspecific hybrids of oil palm. 

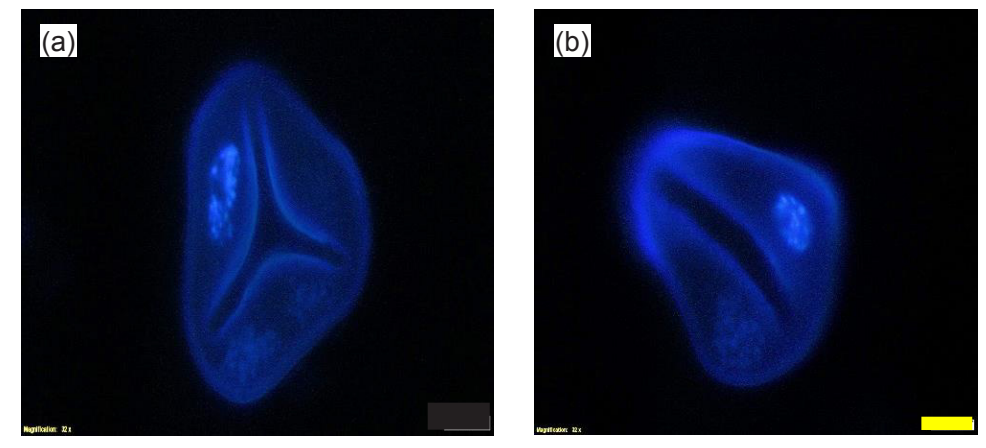

Figure 6. Trichotomosulcate pollen aperture in E. guineensis (a), and monosulcate pollen aperture in E. oleifera (b) $($ bar $=20 \mu \mathrm{m})$.

\section{CONCLUSION}

This study delves into the basic male meiosis process in an oil palm interspecific hybrid, recording its different stages. The meiosis profile of the oil palm interspecific hybrid was consistent with that observed in other plants species, including $E$. guineensis and E. oleifera. The information, especially the clear delineation of the different stages, will facilitate other applied experiments, such as in situ hybridisation of chromosomes at the particular stages in oil palm breeding. The preliminary results reported will be a spring board for future more in-depth studies on the topic. Moreover, the different pollen morphologies will greatly assist in differentiating the different oil palm types. As expected, the aperture numbers in pollen differed between E. oleifera (only one) and E. guineensis (three). Hybrid pollen was a hodgepodge of shapes between the two parental types, but more work is required to ascertain the maternal effect on the pollen shape.

\section{ACKNOWLEDGEMENT}

The authors would like to thank the Director-General of MPOB for permission to publish this article. Thanks also to the MPOB Cytogenetics Laboratory (SitogenLab) Research Assistants, in particular, Ms Zainab Anip and Mr Mohamad Razali Mohd Noor, for their assistance.

\section{REFERENCES}

Abd El-Twab, M H and Kondo, K (2007). Meiotic chromosome organization and segregation in F1 intergeneric hybrid between Chrysanthemum horaimontanum and Nipponanthemum nipponicum by GISH identification. Chrom. Bot., 2: 121-125.

Able, J A; Crismani, W and Boden, S A (2009). Understanding meiosis and the implications for crop improvement. Functional Plant Biol., 36: 575588.

Amiruddin, M D; Kushairi, A; Rajanaidu, N; Isa Zainol, M A; Noh, A and Junaidah, J (2004). Elaeis oleifera oil - A potential source of carotene. Paper presented at the Oils and Fats International Congress (OFIC) 2004. 29 September-2 October 2004. Putra World Trade Centre (PWTC), Kuala Lumpur.

Anamthawat-Jonsson, $\mathrm{K}$ and Heslop-Harrison, J S (1995). Establishing relationships between closely related species using total genomic DNA as a probe. Methods in Molecular Biology Species Identification Protocols (Clapp, J P ed.). Humana Press, Totowa, 50: 209-225.

Armstrong, S J; Sanchez-Moran, E and Franklin, F C H (2009). Cytological analysis of Arabidopsis thaliana meiotic chromosomes in Meiosis, Vol 2: Cytological Methods (Scott, K ed.). Humana Press, 558: 131-145. DOI:10.1007/978-1-103-5_9.

Ata, A; Keles, D; Taskin, H and Buyukalaca, S (2019). Effects of season, genotype and nutrient medium on pepper anther culture and microspore development. Turkish J. Agri. and Forestry, 43: 123-137.

Barcelos, E; Rios, S A; Cunha, R N V; Lopes, R; Motoike, S Y; Babiychuk, E; Skirycz, A and Kushnir, $S$ (2015). Oil palm natural diversity and the potential for yield improvement. Frontiers in Plant Science, 6: 190. DOI: 10.3389 / fpls.2015.00190.

Belandres, H R; Waminal, N E; Hwang, Y-J; Park, B-S; Lee, S-S; Huh, J H and Kim, H H (2015). FISH karyotype and GISH meiotic pairing analyses of a stable intergeneric hybrid xBrassicoraphanus line BB\#5. Kor. J. Hort. Sci. Technol., 33(1): 83-92.

Choo, Y M; Ma, A N and Yap, S C (1997). Carotenes, vitamin $\mathrm{E}$ and sterols in oils from $E$. guineensis, $E$. oleifera and their hybrids. Palm Oil Developments, 27: 1-9. 
Choo, Y M and Yusof, B (1996). Elaeis oleifera palm for the pharmaceutical industry. PORIM Information Series No. 42.

Corley, R H V and Gray, B S (1976). Growth and morphology. Development in Crop Science Vol. 1 (Corley, R H V; Hardon, J J and Wood, B J eds.). Elsevier, Amsterdam. p. 493-503.

Corley, R H V and Tinker, P B (2003). The Oil Palm. Fourth edition. Blackwell Science Ltd, Oxford. 592 pp.

De Farias, M P; De Capdeville, G; Falcao, R; De Moraes, P B; Leao, A P; Camillo, J; Da Cunha, R N V; Alves, A A and Junior, M T S (2018). Microscopic characterization of American oil palm (Elaeis oleifera (Kunth) Cortes) floral development. Flora, 243: 88100.

Doyle, J J and Doyle, J L (1990). Isolation of plant DNA from fresh tissue. Focus, 12: 13-15.

Escobar, R and Alvorado, A (2003). Strategies in the production of oil palm compact clones and seeds. Proc. of the PIPOC 2003 International Palm Oil Congress - Agriculture Conference. p. 75-90.

Figueroa, D M and Bass, H W (2012). Development of pachytene FISH maps for six maize chromosomes and their integration with other maize maps for insights into genome structure variation. Chromosome Res. 20(4): 363-380. DOI:10.1007/ s10577-012-9281-4.

Franssen, A S; Skinner, D Z; Al-Khatib, K and Horak, M J (2001). Pollen morphological differences in Amaranthus species and interspecific hybrids. Weed Science, 49(6): 732-737.

Fukuhara, S; Muakrong, N; Kikuchi, S; Tanya, P; Sassa, H; Koba, T and Srinives, P (2016). Cytological characterization of an interspecific hybrid in Jatropha and its progeny reveals preferential uniparental chromosome transmission and interspecific translocation. Breeding Science, 66(5): 838-844. DOI:10.1270/jsbbs.16069.

Gao, A; Shi, J and Liang, X (2016). Research on meiotic chromosome pairing in Roegneria sinica var. media evaluated using genomic in situ hybridization. Plant Biotech. Rep., 10: 129-139.

Grimsson, F; Van Valkenburg, J L C H; Wieringa, J J; Xafis, A; Jacobs, B N and Zetter, R (2018). Pollen morphology of the African Sclerosperma (Arecaceae). Grana, 58(2): 99-113.

Hardon, J J (1969). Interspecific hybrids in the genus Elaeis. II. Vegetative growth and yield of F1 hybrids E. guineensis x E. oleifera. Euphytica, 18: 380-388.
Hardon, J J and Tan, G Y (1969). Interspecific hybrids in the genus Elaeis I. Crossability, cytogenetics and fertility of F1 hybrids of E. guineensis x E. oleifera. Euphytica, 18: 372-379.

Harley, M M and Baker, W J (2001). Pollen aperture morphology in Arecaceae: Application within phylogenetic analyses, and a summary of record of palm-like pollen the fossil. Grana, 40(1-2): 45-77. DOI: $10.1080 / 001731301591877$.

Higgins, J D; Wright, K M; Bomblies, Land Franklin, F C H (2014). Cytological techniques to analyze meiosis in Arabidopsis arenosa for investigating adaptation to polyploidy. Frontiers in Plant Science, 4: 546. DOI: 10.3389 /fpls.2013.00546.

Hurel, A; Phillips, D; Vrielynck, N; Mezard, C; Grelon, M and Christophorou, N (2018). A cytological approach to studying meiotic recombination and chromosome dynamics in Arabidopsis thaliana male meiocytes in three dimensions. The Plant J., 95: 385396.

Jazinizadeh, E; Majd, A and Pourpak, Z (2017). Another development and microsporogenesis in date palm (Phoenix dacylifera L.). Pak. J. Bot., 49(1): 331-335.

Ju, Y-Q; Hu, X; Jiao, Y; Ye, Y-J; Cai, M; Cheng, T-R; Wang, J; Pan, H-T and Zhang, Q-X (2019). Fertility analyses of interspecific hybrids between Lagerstroemia indica and L. speciose. Czech J. Genet and Plant Breed, 55(1): 28-34.

Karasawa, M M G; Chiancone, B; Gianguzzi, V; Abdelgalel, A M; Botta, R; Sartor, C and Germana, M A (2016). Gametic embryogenesis through isolated microspore culture in Corylus avellana L. Plant Cell, Tissue and Organ Culture, 124(3): 635-647.

Kim, J S; Islam-Faridi, M N; Klein, P E; Stelly, D M; Price, H J; Klein, R R and Mullet, J E (2005). Comprehensive molecular cytogenetic analysis of sorghum genome architecture: Distribution of euchromatin, heterochromatin, genes and recombination in comparison to rice. Genetics, 171: 1963-1976.

Latif, A M; Zaki, N M; Nordiana, H M N; Marjuni, M; Che Radziah, C M Z and Madon, M (2014). Correlation of microspore nuclear development with male inflorescence morphology in Elaeis oleifera, Elaeis guineensis and the OxG hybrid. J. Oil Palm Res. Vol. 26(1): 104-108.

Latif, M A; Nordiana, H M N; Zaki, N M; Marjuni, M; Che Radziah, C M Z; Riksen, T; Custers, J and Madon, M (2013). Oil palm microspore 
culture: MPOB's experience. Proc. of the PIPOC 2013 International Palm Oil Congress - Agriculture, Biotechnology and Sustainability Conference.

Leitch, A R; Schwarzacher, T; Mosgoller, W; Bennet, M D and Heslop-Harrison, J S (1991). Parental genomes are separated throughout the cell cycle in a plant hybrid. Chromosoma, 101: 206-213.

Li, H and Devaux, P (2001). Enhancement of microspore culture efficiency of recalcitrant barley genotypes. Cell Biol. and Morph., 20: 475-481.

Lou, Q; He, Y; Cheng, C; Zhang, Z; Li, J; Huang, S and Chen, J (2013). Integration of high-resolution physical and genetic map reveals differential recombination frequency between chromosomes and the genome assembling quality in cucumber. PLOS ONE 8(5): e62676.

Madon, M; Arulandoo, X; Sritharan, K; Nordiana, H M N; Muhammad Azwan, Z and Zaki, N M (2018). Short communication: Genomic constitution of oil palm interspecific hybrid crosses monitored by genomic in situ hybridization (GISH). J. Oil Palm Res. Vol. 30(2): 338-344.

Madon, M; Clyde, M M and Cheah, S C (1999). Application of genomic in situ hybridization (GISH) on Elaeis hybrids. J. Oil Palm Res. Vol. (Special Issue): 74-80.

Madon, M; Heslop-Harrison, J S; Schwarzacher, T; Mohd Rafdi, M H and Clyde, M M (2005). Cytological analysis of oil palm pollen mother cells (PMC). J. Oil Palm Res. Vol. 17: 176-180.

Maluszynska, J and Hasterok, R (2005). Identification of individual chromosomes and parental genomes in Brassica juncea using GISH and FISH. Cyto. and Genome Res. 109: 310-314.

Meunier, J (1987). Prospects of E. oleifera x E. guineensis interspecific hybrids. IRHO results. Proc. of ISOPB/PORIM Workshop on Prospects of Interspecific Hybrids (Soh, AC and Rajanaidu, N eds.). p. 11-15.

Murphy, S P and Bass, H W (2012). Genetics and cytology of meiotic chromosome behavior in plants. Plant Cytogenetics, Plant Genetics and Genomics: Crops and Models 4 (Bass, H W and Birchler, J A eds.). 345 pp. DOI:10.1007/978-0-387-70869-0_8.

Nair, P K K (1969). The thesis of pollen based plant research. J. Palynol., 5(1): 49-50.

Nordiana, H M N; Muhammad Azwan, Z; Arulandoo, X; Sritharan, K and Madon, M (2016).
Development of meiotic pachytene chromosomes preparation technique in oil palm interspecific hybrid and backcross $\left(\mathrm{BC}_{2}\right)$, Transactions of Persatuan Genetik Malaysia Vol. 3. Genetics Society of Malaysia. p. 143-146.

Phillips, D; Wnetrzak, J; Nibau, C; Barakate, A; Ramsay, L; Wright, F; Higgins, J D, Perry, R M and Jenkins, G (2013). Quantitative high resolution mapping of $H v M L H 3$ foci in barley pachytene nuclei reveals a strong distal bias and weak interference. J. Exp. Bot., 64(8): 2139-2154. DOI:10.1093/jxb/ert079.

Rahimah, A B; Cheah, S C and Singh, R (2006). Freeze-drying of oil palm (Elaeis guineensis) leaf and its effect on the quality of extractable DNA. J. Oil Palm Res. Vol. 18: 296-304.

Rajanaidu, N; Chin, C W and Jalani, B S (1995). Performance of Elaeis oleifera (Surinam) $\mathrm{x} E$. guineensis hybrids. ISOPB International Seminar. Barranquilla, Colombia.

Rasheed, A A; Perveen, A; Abid, R and Qaiser, M (2016). Pollen morphology of the subfamily Arecoideae Griff. (family-Arecaceae) from Pakistan and Kashmir. Pak. J. Bot., 48(3): 1051-1060.

Ravi Kumar, C and Nair, P K K (1986). Inheritance of exine ornamentation and pollen shape in the interspecific tetraploid hybrids of Gloriosa. Can. J. Bot., 64: 3134-3140.

Rhee, H K; Cho, H R and Kim, K S (2005). Comparison of pollen morphology in interspecific hybrid lilies after in vitro chromosome doubling. Proc. of the IX ${ }^{\text {th }}$ International Symposium on Flower Bulbs. Acta Hot., 673: 639-643.

Schubert, I; Fransz, P F; Fuchs, J and De Jong, J H (2001). Chromosome painting in plants. Methods in Cell Science, 23(1-3): 57-69.

Schwarzacher, T and Heslop-Harrison, J S (2000). Practical in situ hybridization. BIOS Scientific Publishers Ltd, Abindgdon, United Kingdom. 250 pp.

Schwarzacher, T; Anamthawat-Jonsson, $\mathrm{K}$ and Harrison, G E (1992). Genomic in situ hybridization to identify alien chromosomes and chromosome segments in wheat. Theor. Appl. Genet., 84: 778-786.

Singh, R; Ong-Abdullah, M; Low, E T L; Manaf, M A A; Rosli, R; Rajanaidu, N; Ooi, L C L; Ooi, S E; Chan, K-L; Ab Halim, M A; Azizi, N; Jayanthi, N; Bacher, B; Lakey, N; Steven, W S; He, D; Hogan, M; Budiman, M A; Lee, E K; Desalle, R; Kudma, D; Goicoechea, J L; Wing, R A; Wilson, R K; Fulton, R S; Ordway, J M; 
Martienssen, R A and Sambanthamurthi, R (2013). Oil palm genome sequence reveals divergence of interfertile species in Old and New worlds. Nature, 500: 335-339.

Thomas, P T and Thomas, H (1973). Annual Report of the Welsh Plant Breeding Station for 1973.
Aberystwyth, Cambrian News. 85 pp.

Zhong, X B; De Jong, J H and Zabel, P (1996). Preparation of tomato meiotic pachytene and mitotic metaphase chromosomes suitable for fluorescence in situ hybridization (FISH). Chromosome Res., 4: 24-28. 